\title{
Some Criteria for the Recognition of Nocardia madurae (Vincent) Blanchard
}

\author{
By RUTH E. GORDON \\ Institute of Microbiology, Rutgers, The State University, \\ New Brunswick, New Jersey, U.S.A.
}

(Received 28 March 1966)

\begin{abstract}
SUMMARY
A combination of characters for the description and identification of strains of Nocardia madurae, based on the examination of 44 strains, is presented. Although nearly all the 44 strains were received from medical laboratories, a few were isolated from soil. Some of the distinguishing properties of $N$. madurae are compared with those of $N$. asteroides, $N$. caviae, $N$. brasiliensis, $N$. pelletieri and Streptomyces somaliensis.
\end{abstract}

\section{INTRODUCTION}

During a comparative study of strains of mycobacteria, nocardias, and streptomycetes Gordon \& Mihm (1962a) obtained as many strains as possible of Nocardia asteroides (Eppinger) Blanchard from the larger culture collections and collections of investigators interested in the species. Old stock strains, new isolates, and a number of their variants were examined. Properties common to all these strains were used to describe $N$. asteroides and to differentiate it from the other species represented in the collection which formed the basis of that study. As far as possible, this procedure was repeated in searching for criteria by which other species could be recognized.

Although a group of apparently useful properties for delineating Nocardia madurae (Vincent) Blanchard was found early in the study, progress in accumulating strains, particularly freshly isolated ones, to confirm the value of the distinguishing characteristics was very slow. Eventually enough strains of $N$. madurae were acquired from medical laboratories and from soil to provide reasonable assurance that the pattern of reactions presented here would be useful in the separation of $N$. madurae from other nocardias and from the streptomycetes. These reactions by which $N$. madurae can be recognized are compared with the reactions of $N$. asteroides (Eppinger) Blanchard, N. brasiliensis (Lindenberg) Castellani \& Chalmers, $N$. caviae (Erikson) Gordon \& Mihm, N. pelletieri (Laveran) Pinoy, and Streptomyces somaliensis (Brumpt) Waksman \& Henrici. The patterns of reactions by which $N$. caviae, $N$. pelletieri and $S$. somaliensis are characterized, however, are based on very few strains and may be unreliable.

\section{METHODS}

Organisms. The strains listed in Tables 1, 3 and 4 and by Gordon \& Mihm (1962 $a$, b) were compared with each other and also with the other strains of mycobacteria, nocardias and streptomycetes in this collection. 
Tests

The strains were examined according to the procedures described by Gordon (1966) with the following additions:

Hydrolysis of aesculin. The cultures were inoculated into aesculin broth (aesculin, 1 g.; ferric citrate, $\mathbf{0 . 5}$ g.; peptone, 10 g.; NaCl, 5 g.; water, 1000 ml.: Cowan \& Steel, 1965), incubated at $28^{\circ}$, and observed for growth and blackening of the medium at 2, 4 and 6 weeks. A tube of the same broth without aesculin was also inoculated with each culture and used as a control.

Resistance to lysozyme. A solution of $0 \cdot 1 \mathrm{~g}$. lysozyme (Nutritional Biochemicals Corp., Cleveland, Ohio) in $60-65 \mathrm{ml}$. of sterile $0.01 \mathrm{~N}-\mathrm{HCl}$ in a $100 \mathrm{ml}$. volumetric flask was boiled over an open flame for $20 \mathrm{~min}$., and then plugged with sterile cotton-wool, cooled to room temperature, and brought to $100 \mathrm{ml}$. by the addition of sterile $0.01 \mathrm{~N}-\mathrm{HCl}$. Five $\mathrm{ml}$. of the lysozyme solution was mixed with $95 \mathrm{ml}$. of sterile glycerol broth (peptone, $5 \mathrm{~g}$.; beef extract, $3 \mathrm{~g}$.; glycerol, $70 \mathrm{ml}$.; water, $1000 \mathrm{ml}$; $\mathrm{pH} \mathrm{7.0}$ ) and dispensed in $2.5 \mathrm{ml}$. amounts in sterile plugged tubes. A loopful of a 14- to 28-day culture in glucose or glycerol broth was inoculated into a tube of lysozyme broth and into a control tube of glycerol broth. The two tubes were observed for growth after 14 and 28 days of incubation at $28^{\circ}$.

Serial transfer in carbohydrate broth. Flasks of arabinose, mannitol, rhamnose and xylose broths were prepared by adding $10 \mathrm{ml}$. of a $10 \%(\mathrm{w} / \mathrm{v})$ aqueous solution of each carbohydrate, sterilized by autoclaving separately, to $90 \mathrm{ml}$. of sterile broth containing $\left(\mathrm{NH}_{4}\right)_{2} \mathrm{HPO}_{4}, 1 \mathrm{~g}$; $\mathrm{KCl}, 0.2 \mathrm{~g}$; $\mathrm{MgSO}_{4} .7 \mathrm{H}_{2} \mathrm{O}, 0.2 \mathrm{~g}$.; distilled water, $1000 \mathrm{ml}$. (Ayers, Rupp \& Johnson, 1919). The broth was adjusted to $\mathrm{pH} 7 \cdot 0$ before the addition of $15 \mathrm{ml}$. of a $0.04 \%(\mathrm{w} / \mathrm{v})$ solution of bromcresol purple. Each flask was heavily inoculated and incubated at $37^{\circ}$. After 2 or 3 months the remainder of the inoculum and the growth, if any, were pipetted to another flask of the same broth.

\section{RESULTS}

\section{Nocardia madurae (Vincent) Blanchard}

Microscopically, cultures on glycerol agar of the 44, strains of Nocardia madurae listed in Table 1 formed filaments which did not retain carbol fuchsin. The undisturbed colonies on Bennett's agar and on soil extract agar were densely or loosely filamentous. Under the conditions of the examination, 20 of the 44 strains produced aerial hyphae. The aerial hyphae of six of the 20 strains were long, with short curling side branches that segmented into short chains of spores; the aerial hyphae of the remaining 14 strains were sparse and varied from short and straight to long and branching.

After 2 weeks of incubation at $28^{\circ}$ on Bennett's agar, the growth of some cultures was whitish, shiny, spreading, and either flat, coarsely wrinkled or folded. The whitish growth of some cultures contained a scattering of rose-coloured dots, and the crests of the folds of other whitish cultures were rose-coloured. The growth of other strains was beige, spreading, and flat or coarsely wrinkled; the growth of strains 780 and 1253 was reddish orange. Most of the strains did not form aerial hyphae visible to the unaided eye; the cultures of a few strains were, however, thickly coated with aerial hyphae; and others were sparsely coated. Brown, soluble 


\title{
Table 1. Strains identified as Nocardia madurae (Vincent) Blanchard
}

\author{
Laboratory no. \\ Name when received, source, strain name or number \\ N 1070, N 5654 \\ 407 \\ 431 \\ 507 \\ 554 \\ 614 \\ 633 \\ $635,636,791,793$ \\ 686 \\ 706 \\ 742 \\ 751-753 \\ 754 \\ 776, 777 \\ 1189,1190 \\ 1234 \\ * \\ 780 \\ 609 \\ W3632 A \\ 510 \\ 623 \\ 637 \\ 743 \\ 1136 \\ 1210 \\ 571 \\ 1087, 1091 \\ 852 \\ 972 \\ 971 \\ 1092 \\ 1253, 1260 \\ Nocardia madurae (Vincent) Blanchard; NCTC (1070, madura foot; 5654, \\ Persia) \\ N. madurae; Julia M. Coffey, N.Y. State Dept. of Health (47294); J. B. \\ Fischer; N. F. Conant \\ N. madurae; Isabel Christison, Duke Univ.; N. F. Conant (2177); A. \\ González Ochoa (4.15) \\ N. madurae; P. Thibault, Inst. Pasteur, Paris (Tunis) \\ N. madurae; E. N. Azarowicz, Univ. of Calif. (62); C. Halde \\ N. madurae; E. N. Azarowicz (26) \\ N. madurae; A. González Ochoa, Inst. de Salubridad y Enfermedades \\ Tropicales, Mexico (412, mycetoma of the foot) \\ N. madurae; A. González Ochoa (614, mycetoma of the foot; 420, mycetoma \\ of the back; $485 ; 1004$ ) \\ N. madurae; L. Ajello, Communicable Disease Center, Chamblee, Ga. \\ (A-528); J. Lamb (mycetoma) \\ N. madurae; C. W. Emmons, Nat. Inst. of Health, Bethesda, Md. (9979); \\ J. Lamb (mycetoma) \\ N. madurae; J. D. Schneidau, Jun., Tulane Univ. (339, madura foot) \\ N. madurae; J. E. Mackinnon, Inst. de Higine, Montevideo (IHM 769, \\ Chile; IHM 869, North Africa; IHM 1154, India) \\ N. madurae; J. E. Mackinnon (Iнм 1390); A. González Ochoa (case 444, \\ madura foot) \\ N. madurae; Jacqueline Walker, London School of Hygiene and Tropical \\ Medicine (A. 260, A. 261; mycetoma pedis) \\ N. madurae; A. E. deArêa Leão, Inst. Oswaldo Cruz, Rio de Janeiro (1078, \\ 2593) \\ N. madurae; G. Altmann, Tel Hashomer Government Hosp., Israel (тн 5, \\ mycetoma pedis) \\ N. madurae; Mary P. Lechevalier, Rutgers Univ. (P 56, Sal 1; soil) \\ N. pelletieri; Jacqueline Walker (A. 292 (9972)) \\ N. pseudomadurae; E. N. Azarowicz (4) \\ Nocardia sp.; G. Altmann, Military Hosp. No. 5, Israel (madura foot) \\ Nocardia sp.; P. Thibault (madura foot) \\ Nocardia sp.; E. N. Azarowicz (47) \\ Nocardia sp.; A. González Ochoa (486) \\ Nocardia sp.; Lucille K. Georg, Communicable Disease Center, Chamblee, \\ Ga.; I. W. Kuhl (madura foot) \\ Nocardia sp.; Joan M. Mihm, Rutgers Univ. (B-2, soil) \\ Nocardia sp.; J. B. Fischer, Ontario Dept. of Health, Toronto (356, gluteal \\ abscess) \\ Proactinomyces pseudomadurae Baldacci; N. M. McClung, Univ. of Kansas \\ (3); Centraalbur. v. Schimmelcultures \\ Streptomyces albus; H. D. Tresner, Am. Cyanamid Co., Pearl River, N.Y. \\ (A0-927-M-811, A0-928) \\ S. madurae (Vincent) González Ochoa \& Sandoval; L. Briceño Iragorry, \\ Univ. Central de Venezuela (FMC N. 107, Sablac; mycetoma of the foot) \\ S. madurae; Mildred Feo, Univ. Central de Venezuela (FMc 96); D. Borelli \\ (mycetoma of the foot) \\ S. pelletieri (Laveran) Waksman \& Henrici; Mildred Feo (FMC 92); A. \\ González Ochoa (thoracic mycetoma) \\ S. madurae; A. González Ochoa (4088, mycetoma of the foot) \\ S. madurae; F. Mariat, Inst. Pasteur, Paris (7087 B, 812) \\ * Two strains not added to this collection.
}

pigment was produced by some cultures, and a purple, soluble pigment by others. The appearance of the strains isolated from soil did not differ from that of strains from other sources. Because the growth of strains 571 and 609, received as Nocardia 
pseudomadurae and Proactinomyces pseudomadurae, was whitish and beige, respectively, the pink and red pigments originally ascribed to them by Baldacci (1944) were presumably lost during cultivation in vitro.

The following combination of physiological properties (Table 2) was found to differentiate all 44 strains of Nocardia madurae from the other strains in our

Table 2. Comparison of physiological characteristics ( $\%$ positive strains)

Property

Decomposition of Adenine

Casein

Hypoxanthine

Tyrosine

Urea

Xanthine

Growth at

$50^{\circ}$

$45^{\circ}$

$40^{\circ}$

$35^{\circ}$

$28^{\circ}$

$10^{\circ}$

Survival at $50^{\circ}$ for $8 \mathrm{hr}$

Nitrite from nitrate

Resistance to lysozyme

Utilization of

Citrate

Malate

Succinate

Hydrolysis of

Aesulin

Starch

Acid from

Adonitol

Arabinose

Erythritol

Galactose

Glucose

Inositol

Lactose

Maltose

Mannitol

Mannose

Melibiose

$\alpha$ - $m$-D-glucoside

Raffinose

Rhamnose

Sorbitol

Trehalose

Xylose

$\begin{array}{ccc}\text { Nocardia } & \text { Nocardia } & \text { Streptomyces } \\ \text { madurae } & \text { pelletieri } & \text { somaliensis } \\ \text { (44 strains) } & \text { (15 strains) } & \text { (22 strains) }\end{array}$

0
100
100
86
0
0

0
100
100
100
0
0

0

100

100

0

0

o

36
98

98
100

100

0

100

100

5

7

67

100

100

100

13

100

100

o

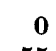

55

91

100

100

9

50

0

0

80

84

18

7

53

37

80

0

45

100

0

0

100

13

41

91
100
0
84
100
61
55
55
100
89
0
0
0
100
0
96
100

$\mathbf{0}$
$\mathbf{0}$
$\mathbf{0}$
$\mathbf{0}$
$\mathbf{5 0}$
$\mathbf{0}$
$\mathbf{0}$
$\mathbf{6 4}$
$\mathbf{0}$
$\mathbf{5}$
$\mathbf{0}$
$\mathbf{0}$
$\mathbf{0}$
$\mathbf{0}$
$\mathbf{0}$
$\mathbf{0}$
$\mathbf{0}$

collection: decomposed casein and hypoxanthine; did not attack adenine, urea or xanthine; grew at $40^{\circ}$; survived $50^{\circ}$ for $8 \mathrm{hr}$; reduced nitrate to nitrite; were senstive to lysozyme; hydrolysed aesculin and starch; acid formed from arabinose, 
glucose, mannitol, rhamnose, trehalose and xylose; unable to produce acid from erythritol, melibiose, $\alpha-m$-D-glucoside, raffinose or sorbitol. Utilization of citrate, malate and succinate; decomposition of tyrosine; and the formation of acid from adonitol, galactose and mannose were less dependable characters of $N$. madurae.

\title{
Table 3. Strains identified as Nocardia pelletieri (Laveran) Pinoy
}

\author{
Laboratory no. Name when received, source, strain name or number \\ 677 \\ 408 \\ 513, 514 \\ 610 \\ 687 \\ 705 \\ 741 \\ 755 \\ 756 \\ 757 \\ 778,781 \\ 779 \\ N 4162 \\ Nocardia africana Pijper \& Pullinger; E. N. Azarowicz, Univ. of Calif. (152); \\ Inst. Pasteur (84) \\ N. pelletieri (Laveran) Pinoy; Julia M. Coffey, N.Y. State Dept. of Health \\ (47293) \\ N. pelletieri; P. Thibault, Inst. Pasteur, Paris \\ N. pelletieri; E. N. Azarowicz, Univ. of Calif. (10) \\ N. pelletieri; L. Ajello, Communicable Disease Center, Chamblee, Ga. \\ (436); N.F. Conant (989) \\ N. pelletieri; C. W. Emmons, Nat. Inst. of Health, Bethesda, Md. (9971); \\ E. C. Smith (Naudi, mycetoma) \\ N. pelletieri; J. D. Schneidau, Jun., Tulane Univ. (305); C. Lacaz (293) \\ N. pelletieri; J. E. Mackinnon, Inst. de Higiene, Montevideo (Iнм 614); Lab. \\ de Parasitologie, Faculté de Médecine, Paris \\ N. pelletieri; J. E. Mackinnon (IHM 615); A. Pijper (Actinomyces africanus) \\ N. pelletieri; J. E. Mackinnon (IHM 1342, Abbot's) \\ N. pelletieri; Jacqueline Walker, London School of Hygiene and Tropical \\ Medicine (A. 290, A. 293); E. C. Smith (mycetoma of the arm, mycetoma of \\ the foot) \\ N. pelletieri; Jacqueline Walker (A. 291, Merucci's) \\ Streptomyces pelletieri (Laveran) González Ochoa \& Sandoval; NCTc (4162); \\ J. T. Duncan; E. C. Smith (Naudi)

\section{Nocardia pelletieri (Laveran) Pinoy}

Cultures on glycerol agar of the 15 strains of Nocardia pelletieri in our collection (Table 3) were filamentous and not acid-fast. Their colonies on soil extract agar and Bennett's agar were loosely or densely filamentous and did not exhibit aerial hyphae. One strain (757) on tyrosine and other agars, however, showed irregularly branching aerial hyphae.

Macroscopically the cultures after 2 weeks of incubation on Bennett's agar were pink, bright red, or dark red with a brownish, almost metallic tinge. Some were flat or coarsely wrinkled and spreading; others resembled a scattering of red-stained bread crumbs on the surface of the slant; and some formed a reddish brown soluble pigment.

During the cultivation of stock cultures of Nocardia pelletieri on Waksman's 'yeast dextrose' agar, beige-coloured variants developed spontaneously from strains 755 and 779.

The following pattern of physiological reactions of the strains of Nocardia pelletieri, separated them from the other strains in this collection: disintegrated casein, hypoxanthine and tyrosine; did not decompose adenine, urea or xanthine; grew at $40^{\circ}$; survived at $50^{\circ}$ for $8 \mathrm{hr}$; reduced nitrate to nitrite; were sensitive to lysozyme; did not hydrolyse aesculin; formed acid from glucose and trehalose; did not produce acid from the remaining carbohydrates listed in Table 2.

Several unsuccessful attempts were made to obtain variants of strains of Nocardia pelletieri capable of forming acid from arabinose, mannitol, rhamnose and xylose 
and thus to resemble strains of $N$. madurae. In one attempt, cultures of $N$. pelletieri were transferred serially in arabinose, mannitol, rhamnose or xylose broths for $\mathbf{1 8}$ months. Although several of the resulting cultures lost their bright red pigment and became yellowish or beige in colour, none of them produced acid from any of the four carbohydrates.

\section{Streptomyces somaliensis (Brumpt) Waksman \& Henrici}

Cultures on glycerol agar of the 22 strains of Streptomyces somaliensis listed in Table 4 were filamentous and not acid-fast. The colonies of the 22 strains on soil extract agar and Bennett's agar were loosely or densely filamentous. Straight aerial hyphae which varied in length and branching were formed sparsely or abundantly by 13 of the 22 strains. Sporulation was not observed.

\section{Table 4. Strains identified as Streptomyces somaliensis} (Brumpt) Waksman \& Henrici

\begin{tabular}{|c|c|}
\hline Laboratory no. & d, source, strain name or number \\
\hline 32 & $\begin{array}{l}\text { Actinomyces somaliensis (Brumpt) St John-Brooks; A. } \\
\text { de Salubridad y Enfermedades, Mexico, D. F. (1064) }\end{array}$ \\
\hline \$3 & $\begin{array}{l}\text { Streptomyces pelletieri (Laveran) Waksman \& Henrici; NCтC (3026); J. T. } \\
\text { Duncan; E. C. Smith (mycetoma) }\end{array}$ \\
\hline 719 & $\begin{array}{l}\text { S. somaliensis (Brumpt) Waksman \& Henrici; G. Altmann, Tel Hashomer } \\
\text { Hosp., Israel (TH/4, mycetoma pedis) }\end{array}$ \\
\hline 126 & $\begin{array}{l}\text { S. somaliensis; F. Mariat, Inst. Pasteur, Paris (313, 314, 315); J. Walker } \\
\text { (A. 311, A. 310, A. 312) }\end{array}$ \\
\hline & S. $s$ \\
\hline $1278-1282$ & 746) \\
\hline & \\
\hline & I. G. Murray $(1071,1070)$ \\
\hline
\end{tabular}

The macroscopic appearance of the cultures of Streptomyces somaliensis grown on Bennett's agar for 2 weeks was not uniform. The growth was flat, finely or coarsely wrinkled, or warty; pigments were whitish, yellowish, beige, beige with a scattering of dark brown dots on the surface, or cocoa brown. Only four cultures had a coating of whitish aerial hyphae visible to the unaided eye; a few cultures formed a brown soluble pigment.

Physiological characteristics for recognizing the 22 strains of Streptomyces somaliensis (Table 2) were the clearing of casein and tyrosine; inability to decompose adenine, hypoxanthine, urea or xanthine; growth at $40^{\circ}$; failure to reduce nitrate to nitrite or to hydrolyse aesculin; sensitivity to lysozyme; and, with the exception of glucose and maltose, lack of acid production from carbohydrates. Eleven of the 22 strains formed acid from glucose, and 14 strains formed acid from maltose. Among the properties listed in Table 2, only decomposition of hypoxanthine, reduction of nitrate to nitrite, and acid formation from trehalose differentiated the strains of Nocardia pelletieri from those of $\boldsymbol{S}$. somaliensis.

\section{Comparison of six species}

The more useful properties for recognizing Nocardia madurae, $N$. pelletieri and Streptomyces somaliensis, presented in Table 2, are compared with those of $N$. asteroides, $N$. caviae and $N$. brasiliensis (Gordon \& Mihm, 1962a, b) in Table 5. 
Although acid-fastness was a variable character of $N$. asteroides, $N$. caviae and $N$. brasiliensis, acid-fastness, when observed, was most helpful in identifying strains of these three species. Resistance to lysozyme was a reliable property of $N$. asteroides, $N$. caviae, $N$. brasiliensis and also of $S$. lavendulae and $S$. rimosus. Strains of $N$. madurae, $N$. pelletieri, $S$. somaliensis, $S$. griseus and $S$. fradiae were sensitive to lysozyme. Strains of $N$. asteroides, $N$. caviae and $N$. brasiliensis were also separated from those of $N$. madurae, $N$. pelletieri and $S$. somaliensis by decomposition of urea, and from $N$. pelletieri and $S$. somaliensis by hydrolysis of aesculin.

Table 5. Some criteria for identifying six species of Nocardia and Streptomyces $\%$ Positive strains.

\begin{tabular}{|c|c|c|c|c|c|c|}
\hline Property & $\begin{array}{c}\text { Nocardia } \\
\text { asteroides } \\
\text { (142 strains) }\end{array}$ & $\begin{array}{c}\text { Nocardia } \\
\text { caviae } \\
\text { (21 strains) }\end{array}$ & $\begin{array}{c}\text { Nocardia } \\
\text { brasiliensis } \\
\text { (62 strains) }\end{array}$ & $\begin{array}{c}\text { Nocardia } \\
\text { madurae } \\
\text { (44 strains) }\end{array}$ & $\begin{array}{c}\text { Nocardia } \\
\text { pelletieri } \\
\text { (15 strains) }\end{array}$ & $\begin{array}{c}\text { Streptomyces } \\
\text { somaliensis } \\
\text { (22 strains) }\end{array}$ \\
\hline Acid-fastness & 51 & 76 & 80 & $\mathbf{0}$ & $\mathbf{0}$ & 0 \\
\hline $\begin{array}{l}\text { Decomposition o } \\
\text { Casein }\end{array}$ & of & o & 98 & 100 & 100 & 100 \\
\hline Hypoxanthine & 4 & 100 & 94 & 100 & 100 & $\mathbf{0}$ \\
\hline Tyrosine & 2 & $\mathbf{0}$ & 100 & 86 & 100 & 100 \\
\hline Urea & 97 & 100 & 100 & $\mathbf{0}$ & $\mathbf{0}$ & $\mathbf{0}$ \\
\hline Xanthine & 0 & 100 & 0 & 0 & 0 & o \\
\hline $\begin{array}{l}\text { Survival at } \\
50^{\circ} \text { for } 8 \mathrm{hr}\end{array}$ & 93 & 86 & $\mathbf{0}$ & 100 & 100 & 50 \\
\hline $\begin{array}{l}\text { Nitrite from } \\
\text { nitrate }\end{array}$ & 88 & 100 & 90 & 100 & 100 & $\mathbf{0}$ \\
\hline $\begin{array}{l}\text { Resistance to } \\
\text { lysozyme* }\end{array}$ & 99 & 100 & 100 & 5 & $\mathbf{0}$ & $\mathbf{0}$ \\
\hline $\begin{array}{l}\text { Hydrolysis of } \\
\text { aesculin }\end{array}$ & $100 \dagger$ & 100 & $100 \dagger$ & 100 & 0 & $\mathbf{0}$ \\
\hline Acid from & & & & & & \\
\hline Adonitol & 0 & 0 & 0 & 91 & $\mathbf{0}$ & o \\
\hline Arabinose & $\mathbf{0}$ & $\mathbf{0}$ & $\mathbf{0}$ & 100 & $\mathbf{0}$ & $\mathbf{0}$ \\
\hline Glucose & 97 & 100 & 97 & 100 & 100 & 50 \\
\hline Inositol & $\mathbf{3}$ & 100 & 100 & 61 & $\mathbf{0}$ & $\mathbf{0}$ \\
\hline Mannitol & 1 & 90 & 94 & 100 & 7 & $\mathbf{0}$ \\
\hline Rhamnose & 32 & 5 & $\mathbf{0}$ & 100 & 0 & $\mathbf{0}$ \\
\hline Trehalose & - & - & 一 & 96 & 93 & $\mathbf{0}$ \\
\hline Xylose & 0 & $\mathbf{5}$ & $\mathbf{0}$ & 100 & $\mathbf{0}$ & $\mathbf{0}$ \\
\hline
\end{tabular}

* 21 strains of Streptomyces lavendulae were resistant to lysozyme; 29 of 30 strains of S. rimosus were resistant; 23 strains of $S$. fradiae and 25 strains of $S$. griseus were not resistant. $\dagger 50$ strains examined.

Under the conditions of examination, the 142 strains of Nocardia asteroides in this collection (Table 5) were differentiated from $N$. caviae and $N$. brasiliensis by their inability to dissolve casein, hypoxanthine, tyrosine or xanthine; survival at $50^{\circ}$ for $8 \mathrm{hr}$, and failure to form acid from inositol or mannitol. Although the strains of $N$. caviae resembled the strains of $N$. asteroides in many respects, $N$. caviae differed from $N$. asteroides in decomposing hypoxanthine and xanthine and in the production of acid from inositol and mannitol. The strains of $N$. brasiliensis attacked casein, hypoxanthine and tyrosine but not the crystals of xanthine; did not survive $50^{\circ}$ for $8 \mathrm{hr}$; and formed acid from inositol and mannitol. 


\section{DISCUSSION}

Nocardia madurae, $N$. pelletieri and Streptomyces somaliensis have been accepted as separate species by many investigators, and the distinctiveness of the three aggregates has been demonstrated by different workers in different ways. Disagreement on certain properties of the strains due to the use of different media and methods has occurred, but in my opinion this disagreement is relatively unimportant, because media and procedures are constantly changing. If today's workers recognize a taxonomic unit by different means, the investigators of the future will also recognize the same unit by procedures as yet unknown.

Confirmation is offered here (Table 3) for the assignment of Nocardia africana Pijper \& Pullinger (1927) to the synonymy of $N$. pelletieri by González Ochoa \& Vázquez Hoyos (1953), Conant et al. (1954), Mackinnon \& Artagaveytia-Allende (1956) and Mariat (1958). An assignment of Proactinomyces pseudomadurae Baldacci (1944) to the synonymy of $N$. madurae (Table 1 ) by other workers was not found, although Mariat (1962) recognized rose- and red-pigmented strains from southern Europe and northern Africa as $N$. madurae.

While investigators apparently agree on the specific status of Nocardia madurae, $N$. pelletieri and Streptomyces somaliensis, the generic location of these three species is still unsettled. Waksman \& Henrici (1948) transferred N. pelletieri (Laveran, 1906) Pinoy (1912) and N. somaliensis (Brumpt, 1906) Chalmers \& Christopherson (1916) to the genus Streptomyces, and González Ochoa \& Sandoval (1955) transferred $N$. madurae (Vincent, 1894) Blanchard (1896) to Streptomyces. These assignments, based on morphology, were accepted by Mackinnon \& Artagaveytia-Allende (1956), Mariat (1958, 1962), Lynch \& Moghraby (1961), Emmons, Binford \& Utz (1963), and others.

Study of a goodly number of strains of nocardias and streptomycetes from a variety of sources revealed, however, that under the conditions of examination the characteristics of acid-fastness, fragmentation of the substrate hyphae, abundance of aerial hyphae, and segmentation of the aerial hyphae into chains of spores, used for the separation of the genera Nocardia and Streptomyces, were variable for $N$. asteroides; and that the properties of fragmentation of the substrate hyphae and formation of aerial hyphae and spores were variable for the streptomycetes (Gordon \& Mihm, 1962a). Physiological criteria to separate the two genera were not found. The observation by Sohler, Romano \& Nickerson (1958) that resistance to lysozyme could not be used for the separation of nocardias from streptomycetes, a retraction of an earlier report by Romano \& Sohler (1956), is confirmed here (Table 5).

A division of the genera Nocardia and Streptomyces based on the chemical composition of the cell wall or of whole cells was offered by Romano \& Nickerson (1956), Sohler, Romano \& Nickerson (1958), Cummins \& Harris (1958), Becker, Lechevalier, Gordon \& Lechevalier (1964), Becker, Lechevalier \& Lechevalier (1965), Yamaguchi (1965), and Murray \& Proctor (1965). These workers demonstrated the presence of meso-diaminopimelic acid and arabinose in the cell-walls or in the whole cells of the nocardias and $L L$-diaminopimelic acid without arabinose in the streptomycetes. Of the strains listed in Tables 1, 3 and 4, 10 of $N$. madurae, three of $N$. pelletieri, and two of $S$. somaliensis were among those examined by Becker et al. 
(1964). The remaining strains of $S$. somaliensis were also found to possess LLdiaminopimelic acid (H. A. \& M. P. Lechevalier, unpublished data). The resulting generic separation was adopted in this report, but not wholeheartedly.

The statement of Cowan \& Steel (1965) that 'The different kinds of bacteria are not separated by sharp divisions but by slight and subtle differences in characters so that they seem to blend into each other and resemble a spectrum', applies to the nocardias and streptomycetes. Morphologically and physiologically, various species of Nocardia and Streptomyces seem to form a spectrum, with $N$. asteroides at one end and $N$. brasiliensis, $N$. madurae, $N$. pelletieri, S. somaliensis, S. lavendulae and $S$. griseus following in that order. Any generic line dividing this spectrum will seem somewhat artificial and arbitrary, because it will assign related species to different genera.

The hierarchial system, the basis of our communication, is not well suited to the naming of the taxonomic units comprising a spectrum. As knowledge of an increasing number of strains and of an increasing number of their characters accumulates, dissatisfaction with the assignment of each strain to a genus and species may become generally widespread and result in a different, internationally adopted, framework of communication (Cowan, 1965). For the present, however, the need of communication dictates the assignment of a generic and a specific name to each taxonomic unit. Currently the meso- or LL-form of diaminopimelic acid and the presence or absence of arabinose in the cells or cell walls appear to be more stable properties than the morphological characteristics of these strains and therefore have been used here for generic separation. Future investigations, perhaps like those of Lanéele, Asselineau \& Castelnuovo (1965) on the lipids of the cells may provide other, more acceptable, generic demarcation in the spectrum of the nocardias and streptomycetes.

This study was supported in part by research grant GB-2579 from the National Science Foundation, Washington, D.C., U.S.A. The author gratefully acknowledges this assistance and that of Dr and Mrs H. A. Lechevalier, who made the chromatographic examination of many of the strains, and of the investigators who kindly provided strains for this study.

\section{REFERENCES}

Ayers, S. H., Rupp, P. \& Johnson, Jun., W. T. (1919). A study of the alkali-forming bacteria found in milk. Bull. U.S. Dept. Agric. no. 782.

Baldacci, E. (1944). Contributo alla sistematica degli Attinomiceti. Atti Ist. bot. Univ. Lab. crittogam Pavia 3, 160.

Becker, B., Lechevalier, M. P. \& Lechevalier, H. A. (1965). Chemical composition of cell-wall preparations from strains of various form-genera of aerobic actinomycetes. Appl. Microbiol. 13, 236.

Becker, B., Lechevalier, M. P., Gordon, R. E. \& Lechevalier, H. A. (1964). Rapid differentiation between Nocardia and Streptomyces by paper chromatography of wholecell-hydrolysates. Appl. Microbiol. 12, 421.

Blanchard, R. (1896). Traité de Pathologie Générale. Ed. by Ch. Bouchard, vol. 2, p. 811. Paris: G. Masson.

Brumpt, E. (1906). Les mycétomes. Arch. Parasit. Paris 10, 489.

Chalmers, A. J. \& Christopherson, J. B. (1916). A Sudanese actinomycosis. Ann. trop. Med. Parasit. 10, 223.

Conant, N. F., Smith, D. T., Baker, R. D., Callaway, J. L. \& Martin, D. S. (1954). Manual of Clinical Mycology, 2nd ed. Philadelphia: W. B. Saunders. 
Cowan, S. T. (1965). Development of coding schemes for microbial taxonomy. In Advances in Applied Microbiology. Ed. by W. W. Umbreit, vol. \%. New York: Academic Press.

Cowan, S. T. \& STEEL, K. J. (1965). Manual for the Identification of Medical Bacteria. Cambridge University Press.

Cummins, C. S. \& Harris, H. (1958). Studies on the cell-wall composition and taxonomy of Actinomycetales and related groups. J. gen. Microbiol. 18, 173.

Emmons, C. W., Binford, C. H. \& Utz, J. P. (1963). Medical Mycology. Philadelphia: Lea and Febiger.

González Ochoa, A. \& Sandoval, M. A. (1955). Characteristicas de los actinomicetes patogenos mas comunes. Revta Inst. Salubr. Enferm. trop., Méx. 16, 149.

González OchoA, A. \& Vázquez Hoyos, A. (1953). Relaciones serologicas de los principales actinomicetes patogenos. Revta Inst. Salubr. Enferm. trop., Méx. 13, 177.

Gondon, R. E. (1966). The taxonomy of soil bacteria. In The Ecology of Soil Bacteria. Ed. by T. R. G. Gray and B. Parkinson. Liverpool University Press. (In the Press.)

Gordon, R. E. \& Mrhm, J. M. (1962a). The type species of the genus Nocardia. J. gen. Microbiol. 27, 1.

Gordon, R. E. \& Mrrm, J. M. (1962b). Identification of Nocardia caviae (Erikson) nov. comb. Ann. N.Y. Acad. Sci. 98, 628.

Lanéele, M.-A., Asselineau, J. \& Castelnuovo, G. (1965). Études sur les mycobactéries et les nocardiae. IV. Compositions des lipides de Mycobacterium rhodochrous, $M$. pellegrino sp., et de quelques souches de nocardiae. Annls Inst. Pasteur, Paris 108, 69.

Laveran, M. (1906). Tumeur provoquée par un microcoque rose en zooglées. C.r. Séanc. Soc. Biol. 61, 340.

LyNCH, J. B. \& Moghraby, I. (1961). Mycetoma in the Sudan associated with Streptomyces madurae. Trans. R. Soc. trop. Med. Hyg. 55, 446.

Mackinnon, J. E. \& Artagaveytia-Allende, R. C. (1956). The main species of pathogenic aerobic actinomycetes causing mycetomas. Trans. R. Soc. trop. Med. Hyg. 50, 31.

Mariat, F. (1958). Physiologie des actinomycétes aérobies pathogènes. Recherches sur l'activité protéolytique et sur la nutrition azotée et carbonée de Nocardia asteroides, $\boldsymbol{N}$. brasiliensis, Streptomyces madurae, S. pelletieri et S. somaliensis. Mycopath. Mycol. appl. 9, 111.

MARIAT, F. (1962). Critères de détermination des principales espèces d'Actinomycétes aérobies pathogènes. Annls Soc. belge Méd. trop. 4, 651.

Murray, I. G. \& Proctor, A. G. J. (1965). Paper chromatography as an aid to the identification of Nocardia species. J. gen. Microbiol. 41, 163.

PiJper, A. \& Pullinger, B. D. (1927). South African nocardiosis. J. trop. Med. Hyg. 30 , 153.

Pinoy, E. (1912). Discussion of paper by A. Thiroux \& J. Pelletier. Mycétome à grains rouges de la paroi thoracique. Isolement et culture d'une nouvelle Oospora pathogène. Bull. Soc. Path. exot. 5, 585.

Romano, A. H. \& Nickerson, W. J. (1956). The biochemistry of the actinomycetales. Studies on the cell wall of Streptomyces fradiae. J. Bact. 72, 478.

Romano, A. H. \& Sohuer, A. (1956). Biochemistry of the actinomycetales. II. A comparison of the cell wall composition of species of the genera Streptomyces and Nocardia. J. Bact. 72, 865.

Sohler, A., Romano, A. H. \& Nickerson, W. J. (1958). Biochemistry of the actinomycetales. III. Cell wall composition and the action of lysozyme upon cells and cell walls of the actinomycetales. J. Bact. 75, 283.

Vincent, M. H. (1894). Étude sur le parasite du 'Pied de Madura'. Annls Inst. Pasteur, Paris 8, 129.

Waksman, S. A. \& Henrici, A. T. (1948). In Bergey's Manual of Determinative Bacteriology, 6th ed. Ed. by R. S. Breed, E. G. D. Murray and A. P. Hitchens, pp. 960, 965. Baltimore: Williams and Wilkins.

YAMAGUCHI, T. (1965). Comparison of the cell-wall composition of morphologically distinct actinomycetes. $J$. Bact. 89, 444 . 